\title{
Porandra microphylla Y. Wan (Commelinaceae): A NEW DISTRIBUTIONAL RECORD FOR VIETNAM
}

\author{
Vu Tien Chinh ${ }^{1 *}$, Tran Thi Phuong Anh ${ }^{1}$, Bui Hong Quang ${ }^{2}$, Nguyen The Cuong ${ }^{2}$ \\ ${ }^{1}$ Vietnam National Museum of Nature, VAST, Vietnam, \\ ${ }^{2}$ Institute of Ecology and Biological Resources, VAST, Vietnam
}

\begin{abstract}
Porandra microphylla Y. Wan, is a new recorded species for the flora of Vietnam. This species was collected from Lai Chau and Vinh Phuc province of the country. Morphologically, P. microphylla is closely related to Porandra scandens D.Y. Hong, but differs by its smaller and abaxially glabrous leaves and oblong or subglobose anthers.
\end{abstract}

Keywords: Commelinaceae, Porandra, P. microphylla, new record, Vietnam.

Citation: Vu Tien Chinh, Tran Thi Phuong Anh, Bui Hong Quang, Nguyen The Cuong, 2016. Porandra microphylla Y. Wan (Commelinaceae): A new distributional record for Vietnam. Tap chi Sinh hoc, 38(3): 340-343. DOI: 10.15625/0866-7160/v38n3.7486.

*Corresponding author: tienchinhvu@gmail.com.

\section{INTRODUCTION}

The genus Porandra D. Y. Hong (Commelinaceae) was firstly described from China [3] based on two species (Thitimetharoch et al. 2003). While studying the genus in Thailand, Thitimetharoch et al. (2003) reported three species from the country, namely P. microphylla, P. ramosa and P. scandens [6]. They also reported distribution of $P$. scandens in Vietnam [5].

During our scrutiny of the unidentified specimens housed in the herbarium of Institute of Ecology and Biological Resources (HN), we came across two accessions of Porandra which after careful examination of the morphological characters, identified as $P$. microphylla Y. Wan. This species was never been recorded from Vietnam, hence we are reporting this as a new record to the country. $P$. microphylla is closely related to $P$. scandens $[2,3]$ but it can be differentiated from the later in having oblong or subglobose anthers; and smaller and abaxially glabrous leaves (table 1).

\section{MATERIALS AND METHODS}

While scrutinizing the specimens housed at HN, we came across two interesting specimens belonging to the genus Porandra. After a thorough examination of the morphological characters, study of relevant literature and the type specimens we identified them as P. microphylla Y. Wan. Specimens housed in the virtual herbaria, such as $\mathrm{PE}, \mathrm{K} \& \mathrm{P}$ were also studied.

\section{RESULTS AND DISCUSSION}

Porandra microphylla Y. Wan, Bull. Bot. Res., Harbin 6(4): 153. 1986; Thitimetharoch et al., Thai For. Bull. (Bot) 31: 142. 2003.

Type: China: Guangxi: Long'an, Longhushan Conservation Area, 16 June 1985, Y. Wan 85011 (Holotype: IBG; Isotype: GXMS!).

Scandent herbs, slightly woody at base. Stems climbing, branched distally; internodes 2$18 \mathrm{~cm}$. Leaf sheaths $1.5-6.5 \mathrm{~cm}$, densely puberulent on one side, mouth long-ciliate; petiole 3-10 mm; leaf blade narrowly ellipticlanceolate, $6-12 \times 1.5-3 \mathrm{~cm}$, with a line of white-hirsute hairs near margin of adaxial surface, abaxially glabrous, base cuneate or obtuse, apex acuminate to caudate. Inflorescence a head ca. $1.5 \mathrm{~cm}$ in diam. Heads with 2-6 flowers; bracts broadly ovate, ca. 2.5 $\mathrm{mm}$, sparsely pubescent. Sepals oblong, carinate, 5-6 × 2-3 mm, pubescent outside. Petals broadly elliptic, $5-6 \times$ ca. $3 \mathrm{~mm}$. Filaments ca. $7 \mathrm{~mm}$, lanate with white hairs; anthers oblong or subglobose, $1-1.2 \times$ ca. $1 \mathrm{~mm}$, dehiscent by apical pores. Ovary sparsely 
puberulent, ca. $1.2 \mathrm{~mm}$. Style ca. $1 \mathrm{~cm}$. Capsule ellipsoid, trigonous, ca. $9 \times 6-7 \mathrm{~mm}$, glabrous.

Distribution: Vietnam: Lai Chau prov. (Binh Lu distr.), Vinh Phuc prov. (Tam Dao National Park); China (Guangxi) and Thailand (Chiang Mai).

Ecology: The species was found growing in evergreen forest, beside the trails or along the streams ca. 1100-1200 m.a.s.l. Flowering \& Fruiting: December - June next year.

Specimens examined: North Vietnam, Vinh Phuc prov., Tam Dao National Park, 12 Oct. 1979, Nguyen Thi Do 15073 (HN); Lai Chau prov., Binh Lu distr., 24 Oct. 1976, Nguyen Thi Nhan 165 (HN).

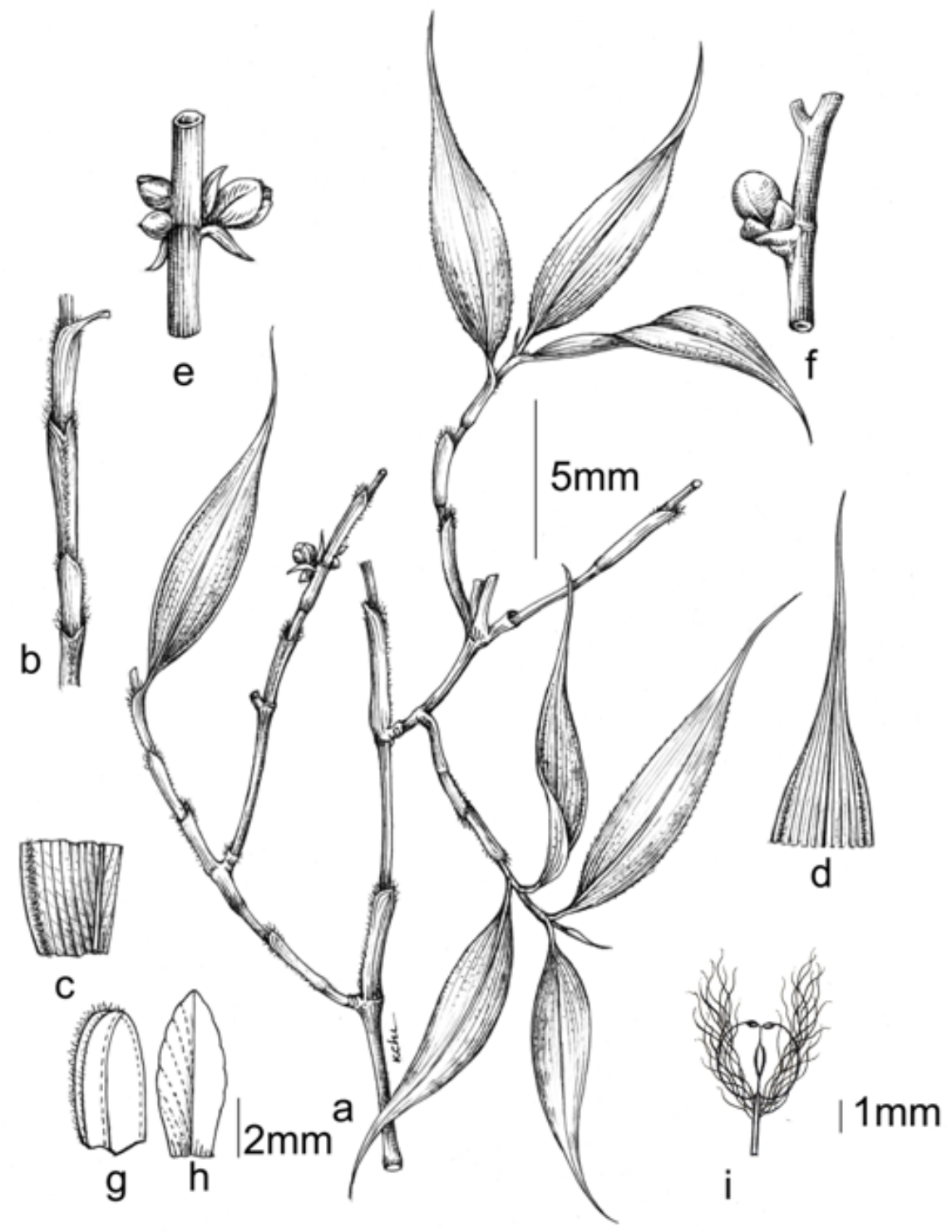

Figure 1. Porandra microphylla Y. Wan

a. Flowering branch; b. Leaf sheath; c. Part of blade showing its adaxial surface; d. Apex of blade; e. Branch with inflorescence; f. Branch with fruit; g. Sepal; h. Petal; i. Filament with long hairs, anthers with apical pores (a-i from 165 and 15073; drawn by Le Kim Chi). 
Note: The characters states considered important for distinguishing these species are given in (table 1). Present report documents a will provide insight for conservation and management of threatened plant species occurring in the country. rare taxon from Vietnam for the first time. This

Table 1. Morphological comparison of P. microphylla and P. scandens.

\begin{tabular}{lll}
\hline Morphological characters & \multicolumn{1}{c}{$P$. microphylla } & \multicolumn{1}{c}{$P$. scandens } \\
\hline Leaf blade & $\begin{array}{l}5-15 \times 1.5-4.5 \mathrm{~cm}, \text { with a line } \\
\text { of white-hirsute hairs near } \\
\text { margin of adaxial surface }\end{array}$ & $\begin{array}{l}10-16 \times 3-4 \mathrm{~cm}, \text { with a line of } \\
\text { hirsute hairs along the margin of } \\
\text { adaxial surface }\end{array}$ \\
\hline Sepals & $\begin{array}{l}\text { carinate, } 5-62-3 \mathrm{~mm}, \text { always } \\
\text { pubescent outside }\end{array}$ & $\begin{array}{l}\text { ellipsoid, } 6-8 \times 4-5 \mathrm{~mm}, \\
\text { glabrous outside }\end{array}$ \\
\hline
\end{tabular}

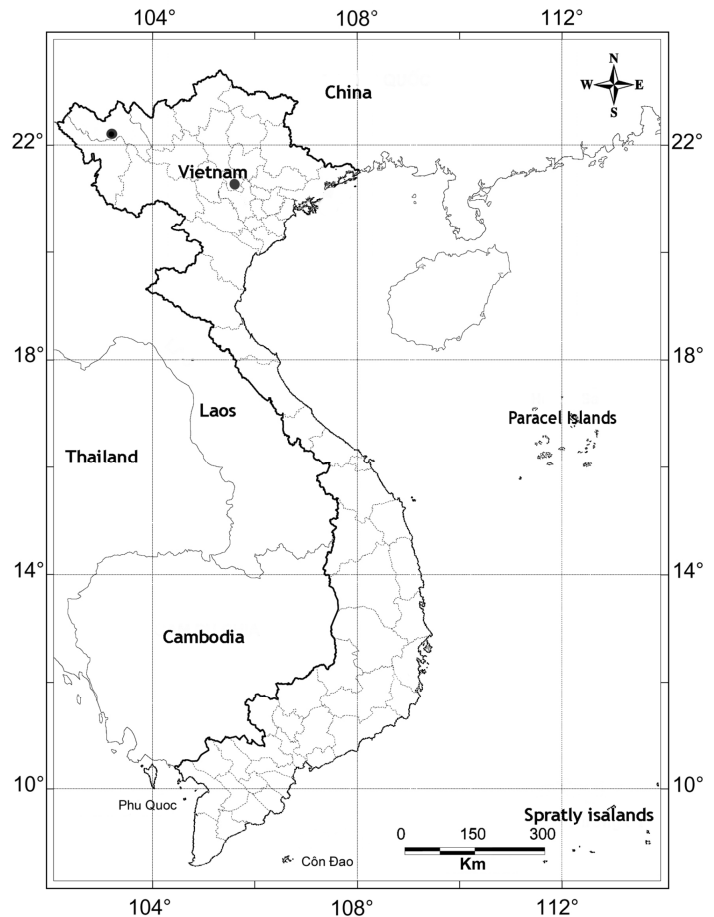

Figure 2. Distribution map showing location of Porandra microphylla Y. Wan. in Vietnam

Acknowledgements: We would like to thank the curators of the herbaria HN, HNU, VHNM, P, K, SCBG, PE \& KUM for help. Partial support received under Project BSTMV.05/14-16 and
IEBR.DT01/15-16 for this research is duly acknowledged. The authors also express their thanks to Mrs. Kim Chi, IEBR, Vietnam for making illustration for the present communication.

\section{REFERENCES}

1. Do N. T., 2003. Comlimenaceae. In: Ban, N.T., (Eds), Commelinaceae. Checklist of plant species of Vietnam, 3: 732-742. Agricultural Publishing House, Hanoi.

2. Faden R. B., 1998. Commelinaceae. The Families and genera of Vascular Plants IV: Flowering plant: Monocotyledons, pp. 109128. Springer-verlag, Berlin.

3. Hong D. Y., $1974 . \quad$ Revisio Commelinacearum Sinicarum. Acta Phytotax. Sinica, 12(4): 459-488.

4. Hong D. Y., De Filipps R. A., 2000. Commelinaceae. In: Flora of China, 24: 1930. Science Press. Beijing and MBG Press.

5. Pham Hoang Ho, 1999. An Illustrated Flora of Vietnam, 3: 234-250. Tre Publishing House, Ho Chi Minh city.

6. Thitmetharoch T., Chanranothai R., Faden R. B., 2003. The Genus Porandra (Commelinaceae) in Thailand. Thai For. Bull. (Bot.), 31: 141-148. 


\title{
BỔ SUNG LOÀI Porandra microphyla Y. Wan (HỌ Commelinaceae) CHO HỆ THỰC VẬT VIẸT NAM
}

\author{
Vũ Tiến Chính ${ }^{1}$, Trần Thị Phương Anh ${ }^{1}$, Bùi Hồng Quang ${ }^{2}$, Nguyễn Thế Cường $^{2}$ \\ ${ }^{1}$ Bảo tàng Thiên nhiên Việt Nam, Viện Hàn lâm KH \& CN Việt Nam \\ ${ }^{2}$ Viện Sinh thái và Tài nguyên sinh vật, Viện Hàn lâm KH \& CN Việt Nam
}

\section{TÓM TẮT}

Chi Porandra ở Việt Nam mới biết 1 loài, bài báo này ghi nhận mới loài $P$. microphylla Y. Wan cho hệ thực vật Việt Nam. Mẫu nghiên cứu được thu tại Vườn quốc gia Tam Đảo, Vĩnh Phúc với số hiệu 15073 và từ Bình Lưu, Lai Châu số hiệu 165 được lưu tại phòng Tiêu bản thực vật, Viện Sinh thái và Tài nguyên sinh vật $(\mathrm{HN})$. Bài báo đưa ra những đặc điểm hình thái, so sánh của hai loài có quan hệ gần nhau là loài $P$. microphylla và $P$. scandens.

Loài $P$. microphylla có các đặc điểm khác biệt với các loài còn lại trong chi này ở Việt Nam là mép lá có lông dày đặc. Bao phấn thuôn dài, loài P. microphylla là ghi nhận mới cho hệ thực vật Việt Nam.

Tư khóa: Commelinaceae, Porandra, P. microphylla, nghi nhận mới, Việt Nam.

Received 3 December 2015, accepted 20 September 2016 